\title{
School Characteristics and Enrollment Trend in Upper Basic Schools in Akwa Ibom State, Nigeria from 2008-2016
}

\author{
Samuel Okpon Ekaette ${ }^{1}$, John A. Ekpenyong ${ }^{1}$, Valentine Joseph Owan ${ }^{1 *}$ \\ ${ }^{1}$ Department of Educational Administration and Planning, University of Calabar, Calabar, NIGERIA
}

*Corresponding Author: owanvalentine@gmail.com

Citation: Ekaette, S. O., Ekpenyong, J. A. and Owan, V. J. (2019). School Characteristics and Enrollment Trend in Upper Basic Schools in Akwa Ibom State, Nigeria from 2008-2016. Pedagogical Research, 4(3), em0039. https://doi.org/10.29333/pr/5855

Published: July 22, 2019

\begin{abstract}
The study investigated school characteristics and enrolment trend in upper basic schools in Akwa Ibom State Nigeria from 2008-2016. Two research questions were answered while two null hypotheses were also tested. The study adopted a descriptive survey research design. Census technique was adopted in selecting all the 227 public upper basic schools in the area of study. An instrument tagged "School Characteristics and Enrolment in Upper Basic Schools Checklist (SCEUBSC)" was used for data collection. Descriptive statistics (percentages) was used to summarize data relating to the research questions, bar chart was used for illustrations of the enrolment pattern while independent t-test was used to test the two null hypotheses at .05 alpha level. Findings revealed that enrolment in upper basic schools in Akwa Ibom State was high in single-sex schools and boarding schools, while it was low in mixed-sex schools and day schools. Based on the findings, it was concluded that there was an upward trend in enrolment in all the schools from 20082013 and a downward trend from 2015-2016. It was recommended among others that research allocation in terms of personnel and infrastructures should be evenly distributed across the state as these will reduce rural-urban migration.
\end{abstract}

Keywords: school characteristics, enrollment trend, basic schools, school type, school composition, Akwa Ibom

\section{INTRODUCTION}

Akwa Ibom State Government funds primary and secondary education in the State through the state budgetary allocation. The state is also responsible for the provision of a conducive teaching/ learning environment through the rehabilitation and reconstruction of schools, provision of science laboratory equipment, construction and renovation of hostels in boarding schools across the State, provision of desks and other infrastructure, payment of the Senior Secondary Certificate Examination (SSCE) fees for all students in public secondary schools, public technical colleges, and the provision of free textbooks for students in all subjects (Ukpong, 2014). This development brought about increased enrolment in primary and secondary schools in Akwa Ibom State, which allowed more children to access basic education in the State.

However, the issues surrounding school enrolment border on access to education and equity in access to education, which is defining factors of equality of educational opportunities or equality in access to education. The increase in school enrolment is supposed to be a balanced development in which access to education is spread evenly across regions in a geographical location, in order to avail children from differing social background and status, opportunities to take advantage of quality education for even development in the society. When there is an increase in school enrolment with unequal access to education, such that quality schools are established in some 
areas, while other areas suffer from poorly equipped schools, it raises a problem of inequality in access to education, which is critically inimical to the wholistic development of the society.

In spite of the remarkable success registered by Akwa Ibom State Government in increasing enrolment at the primary and secondary school levels in the State through the full implementation of the Universal Basic Education (UBE) policy, there seems to be a noticeable gap in the spread of education access among localities in the State, such that quality schools are mostly located in urban areas of the state. This has informed a state of inequality in educational opportunities among Akwa Ibom State children.

Access to education implies making education available for everyone who is entitled to an education, to receive it, while equity in access to education means that all the segments of the society get their fair share of access to whatever educational opportunities provided in the society (the Federal Republic of Nigeria, 2004). Equality in access to education connotes the removal of all obstacles that may prevent anyone from taking advantage of educational opportunities available, thereby granting everyone who is desirous and entitled to education the access to quality education (Babalola, Akpa, Ayeni, and Adedeyi, 2007).

The issue of inequality in access to basic education has been a common trend in Nigeria, despite the huge resources committed to the full implementation of Universal Basic Education in the country. Research has shown that in spite of the progress made in advancing the educational system, achievement in education continues to be very low and the uneven distribution of education across different groups is related to social class differences, socioeconomic background, gender, region, rural/urban location and school factors (Onwuameze, 2013).

Studies have shown that several factors could be held accountable for the poor and uneven access to basic education in Nigeria. While some may have a direct influence on school enrolment, others have an indirect influence. Factors such as school infrastructure, school size, school type and quality of teaching seem to influence enrolment directly in that they determine the quality and type of schools, which can form the basis for increased or reduced enrolment depending on the perception of the populace. Other factors such as location, political influence, social economic status, and gender disparity seem to influence school enrolment indirectly through first, influencing the characteristics of schools, which may then influence enrolment trend in the schools.

However, as a means of providing evidence and contributing to the literature, the focus of this article is on two characteristics of the school including school type and school composition. School type is a critical factor that may exert greatly on school enrolment figures. Some researchers are of the opinion that single-sex schools are more preferred to mixed-sex schools, while others prefer mixed-sex schools to single-sex schools.

For instance, Park, Behrman, and Jaesung (2013) stressed that parents tend to perceive single-sex schools as being superior to coeducational schools. Howell, West, and Peterson (2008) added that more than one-third of Americans support having single-sex public schooling options due to the perceived learning environment associated with single-sex schools. Kessels and Hannover (2008) found out that girls from single-sex physics classes reported a better physics self-concept of ability than girls from coeducational classes. According to them, singlesex schooling was found to help adolescents to gain a better self-concept of ability in school subjects that are considered inappropriate for their own sex.

A study by Sullivan, Joshi, and Leonard (2010) discovered that single-sex schooling is linked to the attainment of gender-stereotyped subject areas for both sexes, not just during the school years, but also later in life. Schmuck (2005) and Smyth (2010) separately disagreed with Leonard and will rather maintain that girls-only schools are unnatural social settings which isolate girls from boys. Mburu (2013) revealed that the type of school attended affected students' academic performance as the majority of the girls who qualified to join tertiary institution were from single-sex schools. The results of Afu, Vivian, Gbobo, Ukofia, and Itakure (2017) showed that preference for private school and socio-economic statuses of parents/guardians were significantly responsible for a gender imbalance in the enrolment of students. More so, a comparison of the perception of respondents at the urban and rural location showed a statistically significant difference.

Kemunto (2013) elicited a number of factors which affect the academic performance of girls in mixed day secondary schools. They include; type of school, physical facilities, parental involvement in education and parental level of education, the proximity of the school and influence of social economic background.Lee, Turner, Woo, and Kim (2014), and Arop and Owan (2018) found that the significant impact of single-sex schools on male students' achievement was not driven by classroom gender composition, but largely accounted for by increases in student effort and study-time.

The study of Garcia-Gracia and Vázquez (2016) indicated that differences in achievement depending on gender in segregated or mixed schools are not related to factors of school organization. teaching practices and the effects of these on self-concept and single-sex school performance. A study carried out by Sullivan, Joshi, and Leonard (2010) revealed that in British schools examining the impact of single-sex schooling found out that single-sex schooling is linked to the attainment of gender-stereotyped subject areas for both sexes, not just during the school years, but also later in life. This agrees with the findings of Doris, O'Neill, and Sweetman (2012) which also 
disclosed that a significant maths gap existed in favour of boys and that the gender differential is larger for children educated in single-sex schools than in co-educational schools.

Gneezy, Niederle, and Rustichini (2003), in their test reactions to competition in maths puzzles by boys and girls, concluded that it is not that women are unwilling or unable to perform well in competitions per se, but rather that they do not compete well in competitions against men. The results of Caskey (2006) led to the conclusions that same-gender grouping did not produce significant differences in students' science academic achievement and same-gender classes did not create a more positive classroom climate. Fabian (2009) uncovered through a study that female participation in teaching has positively affected the enrolment of female students in secondary schools in Nigeria at a 5\% level of significance. In addition, the enrolment of female students at this level of education was not motivated by the presence of male participation in teaching.

In line with this finding, Igberadja (2014) studied what causes low enrolment in technical schools in Delta state, Nigeria based on teachers' perception. The result showed that school factors are among factors responsible for low enrolment in technical schools in Delta state, Nigeria. Kombo (2005) affirmed that the educational attainment of girls is associated with the type of educational institution one attends.

In another study by Anil, Guner, Delibasi, and Uysal (2016) it was revealed that the higher the share of females in a division, the lower the likelihood that a student drops out. It was found that a standard deviation increase in the share of females in the division decreases the likelihood of dropout by 0.3 percentage points. This result also held that even though females are 9.32 percentage points more likely to drop out, these findings are robust to the inclusion of various control variables e.g. parental and academic background of the student, school and regional characteristics. A study also revealed that security is well managed in single-sex schools than in mixed schools (Arop, Ekpang, and Owan, 2018).

The second aspect of this study focused on school composition. The school composition in terms of whether the school is a day or boarding school may have a significant influence on the decision of both students and parents on what school to attend. Jagero (2012) established that most students in Kenya desire to be in boarding schools but could not because they cannot afford the cost of boarding. Ngeno, Enose, and Ayodo (2012) asserted parents and guardians lack guiding principles on making informed decisions on the choice of schools amid limited financial resources.

Empirically, Adetunji and Oladeji (2007) revealed that most of the boarding students read regularly because they have a scheduled time for reading in their curriculum, they sometimes use library and library books. Day students read occasionally, especially during an examination. In their academic performances, boarders are above average while day students are below average. Parents and teachers alike are encouraged to train the mind of our youth towards reading and reduce their home and school chores. This finding implies that more boarding schools may lead to an increase in enrolment in secondary schools.

Ahmed, Oliver, and Danmole (2017) carried out a comparison of boarding and day secondary school students' performance in biology in Owo, Ondo State, Nigeria. The results revealed that there was a significant difference in the Biology students' academic performance in private and public boarding and day secondary schools. The researchers' findings imply that given adequate facilities in both schools, students may perform equally, which may also influence their decision to enrol in the schools.

Kiage, Simatwa, and Ayodo (2014) surveyed the effect of school fees and levies on enrolment of girls in boarding public secondary schools in Transmara Sub County, Kenya. It was established that the beneficiaries of education in boarding schools who could not meet the socioeconomic demands did drop out of schools leading to declining in enrolments and that the average cost of educating a girl in a boarding school informs one to three was Kshs. 39,056 while the cost of educating a girl in boarding school in form four was Kshs. 55,140. The subsidy of Kshs 10,265 only caters for 19 percent of the total cost of educating a girl in boarding school. Lack of boarding fees and other school levies contributed to a decline in enrolment of girls in boarding schools. Failure to implement government policies such as re-admission of teenage mothers to school, providing the needy girls with enough bursaries, stopping early marriages and discrimination of girls in the provision of education influenced the decline of girls' enrolment in boarding schools.

Dang and Bulus (2015) concluded that school composition in terms of boarding or day school may not directly influence enrolment but the level of infrastructural provision in the schools will affect. Anisiudo (2015) revealed that the average cost of students' senior secondary education in Anambra State is N141,680.64 which covered public, private and mission schools. It was also discovered that the mean cost of senior secondary education for students in a boarding school is higher than the cost incurred by the day school students. This finding agrees with that of Dang and Bulus, that boarding or day school may not really influence enrolment in schools but the costs of acquiring education in a particular school may contribute to increase or decrease in enrolment in the school.

The findings of Ogechukwu and Chika (2018) revealed that boarding students academically achieved better than day students, and that day students are distracted at home, unlike boarding school students who are under the control of teachers for their studies. It was concluded that lack of finance, educational facilities, and inadequate 
infrastructures are the factors that affect the academic achievement of both the day and boarding students. The researchers espouse the fact that school composition in terms of boarding and day school may not really have a significant influence on enrolment trend, but the level of facilities provided in schools may shape the decision of students on what school to attend.

Papworth (2014) established that a significant number of students prefer boarding schools due to distance from suitable schools or potential lack of resources in remote or regional areas, parents also believed that attending boarding school represents a choice and access to greater educational resources for their children. Oredein (2016) revealed that school size, ownership, structure, type, and location were statistically significant to students' academic performance in Calabar Municipal Local Government of Cross River State. The implication of this finding is based on the fact that good students' academic performance of students will lead to high enrolment and retention rates while poor students' academic performance will decrease enrolment and results in high school drop-outs. Abdullahi (2010) maintained that there is a significant difference in reading and note taking between day and boarding students' study habits and that home environment compared very unfavourably with a school environment in which the boarders have their schedule planned by the school authorities and the schedules are supervised by the school counsellor or personnel on duty.

The relevant literature reviewed indicated a preponderance of studies conducted on school characteristics and students' achievement, school performance, students' performance, among others. However, it was noted that to the best of the researchers' knowledge that exhaustive direct empirical studies had not been recorded on school characteristics and enrolment trend in Akwa Ibom State especially focusing on junior secondary schools. It was also noted that most of the empirical work reviewed did not use time series analysis. These are the gaps created in which this study is designed to fill.

From the literature reviewed, it was shown that many researchers used school characteristics interchangeably with school variables and that most researchers found that school type and school composition have significant influence on students' choice of school, while others established that these school variables may not directly have influence on students' enrolment, but the level of infrastructural provision in schools. Most studies had focused on the academic performance or achievement of students with less attention to what may determine students' enrolment or choice of school within the specific period of time. This underscores the need for the present study to examine the school characteristics and show how they shape the enrolment trend within 2008 and 2016 in Akwa Ibom State. This is another gap the study is designed to fill.

\section{PURPOSE OF THE STUDY}

The main purpose of this study was to determine the influence of school characteristics on enrolment trends in junior secondary schools in Akwa Ibom State from 2008 - 2016. Specifically, the study sought to examine;

1. The enrolment trend of junior secondary schools from $2008-2016$ based on school type

2. The enrolment trend of junior secondary schools from 2008 - 2016 based on school composition

\section{Research Questions}

The following research questions guided the study;

1. What is the enrolment trend of single-sex and mixed-sex junior secondary schools from $2008-2016$ ?

2. What is the enrolment trend of junior secondary schools from $2008-2015$ in day and boarding schools?

\section{Statement of Hypotheses}

The following hypotheses were stated to direct the study;

1. There is no significant difference in enrolment trend of junior secondary school from $2008-2016$ based on school type

2. There is no significant difference in enrolment trend of junior secondary school from $2008-2016$ based on school composition.

\section{METHODOLOGY}

The research design adopted in this study was a descriptive survey. This design aimed at collecting data and describing in a systematic manner, the characteristics, features or facts about a given population (Nworgu, 2006). The design is only interested in describing certain variables in relation to the population and was chosen because of the descriptive and after event nature of the study.

The study was carried out in the Akwa Ibom State of Nigeria. The state was created on the $23^{\text {rd }}$ of September, 1987, out of the former Cross River State. It lies between latitude 5010' and 4020' North of the Equator and $7^{0} 23^{\prime}$ 
Pedagogical Research, 4(3), em0039

Table 1. The population of junior secondary schools in Akwa Ibom State

\begin{tabular}{ccc}
\hline S/No. & Education zone & No. of schools \\
\hline 1 & Uyo & 84 \\
\hline 2 & Eket & 63 \\
\hline 3 & Ikot Ekpene & 80 \\
\hline & Total & 227
\end{tabular}

Source: Akwa Ibom State Secondary Education Board (2018)

Table 2. Percentages of enrolment in single-sex and mixed-sex junior secondary schools from 2008-2016

\begin{tabular}{lcccccccc}
\hline Years School & $\begin{array}{c}\mathbf{2 0 0 8 / 0 9} \\
\mathbf{( \% )}\end{array}$ & $\begin{array}{c}\mathbf{2 0 0 9 / 1 0} \\
\mathbf{( \% )}\end{array}$ & $\begin{array}{c}\mathbf{2 0 1 0} / \mathbf{1 1} \\
\mathbf{( \% )}\end{array}$ & $\begin{array}{c}\mathbf{2 0 1 1 / 1 2} \\
\mathbf{( \% )}\end{array}$ & $\begin{array}{c}\mathbf{2 0 1 2 / 1 3} \\
\mathbf{( \% )}\end{array}$ & $\begin{array}{c}\mathbf{2 0 1 3} / \mathbf{1 4} \\
\mathbf{( \% )}\end{array}$ & $\begin{array}{c}\mathbf{2 0 1 4 / 1 5} \\
\mathbf{( \% )}\end{array}$ & $\begin{array}{c}\mathbf{2 0 1 5} / \mathbf{1 6} \\
\mathbf{( \% )}\end{array}$ \\
\hline Single-sex & $221(58)$ & $267(57)$ & $311(58)$ & $345(59)$ & $359(59)$ & $380(60)$ & $386(60)$ & $351(60)$ \\
\hline Mixed-sex & $162(42)$ & $202(43)$ & $221(42)$ & $240(41)$ & $247(41)$ & $257(40)$ & $254(40)$ & $232(40)$ \\
\hline Total & 383 & 469 & 532 & 585 & 606 & 637 & 640 & 583 \\
\hline
\end{tabular}

Source: authors' fieldwork, 2018

East of Greenwich Meridian. Akwa Ibom State has boundaries with Cross River State in the North, Bight of Bonny in the South, Rivers State in the South-West, Imo and Abia in the West, while the Cameroon Republic lies in the East.

The population of this study comprised all the public junior secondary school students in Akwa Ibom State. According to the Akwa Ibom State Secondary Education Board (2018), there are a total of 227 public secondary schools spread across the three (3) Education Zones in Akwa Ibom State. This is presented in Table 1.

Census technique was adopted for the study. In using this technique, all the junior secondary schools in Akwa Ibom State were selected for the study. This is because the study made use of secondary data for the entire 227 schools in the state. Data for this study were collected through secondary sources.

The instrument used for data collection was titled "School Characteristics and Enrolment in Junior Secondary Schools Checklist (SCEJSSC)". The checklist contained all the 8 school characteristics considered in the study, listed alphabetically as follows; A-Large school, B-Small school, C-Urban schools, D-Rural schools, E-Single sex schools, F-Mixed sex schools, G-Day schools, H-Boarding schools. The total enrolment of all the schools was recorded based on their characteristics from 2008 to 2016.

In collecting data for this study, a written request was sent to the Chairman, Akwa Ibom State Secondary Education Board in order to be able to access the data needed. Two research assistants were engaged to assist in collating the data provided using the "School Characteristics and Enrolment in Junior Secondary Schools Checklist (SCEJSSC)."

Data collected from the checklist were entered into Microsoft Excel, and then percentages and bar chart were calculated and plotted. Descriptive statistics (summation and mean percentages) were also used to summarize data relating to the research questions; bar chart was used for illustration of the trend, while independent $t$-test was used to test the null hypotheses at .05 level of significance. The results of the study are presented in the following section.

\section{RESULTS}

\section{Research Question 1}

What is the enrolment trend of single-sex and mixed-sex junior secondary schools from $2008-2016$ ? The result of data analysis is presented in Table 2.

The result in Table 2 shows that the trend of enrolment in single-sex junior secondary schools increased steadily from 2008/2009 with an average of 221 up to 2014/2015 with average of 386. In 2015/2016, enrolment trend in single-sex schools dropped to 351. However, the enrolment trend in mixed-sex schools increased consistently with an average of 162 in 2008/2009 up to 2013/2014 with an average mean of 257 and then started falling in 2014/2015 with an average of 254 and continued declining slowly to 232 in 2015/2016. The analysis also indicates that junior secondary school enrolment was significant high in single-sex schools than mixed-sex schools in all the years except in 2016 for single-sex schools and 2014-2016 for mixed-sex schools. This is further illustrated in Figure 1. 


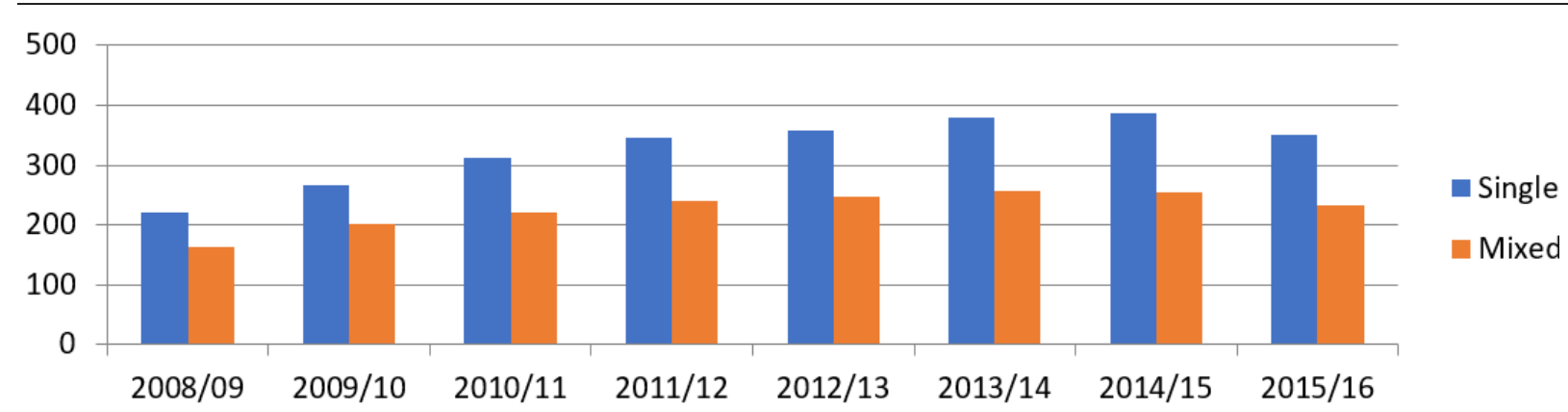

Figure 1. Enrolment trend in single-sex and mixed-sex schools from 2008-2016

Table 3. Percentages of enrolment in day and boarding junior secondary schools from 2008-2016

\begin{tabular}{lcccccccc}
\hline Years School & $\begin{array}{c}\mathbf{2 0 0 8 / 0 9} \\
\mathbf{( \% )}\end{array}$ & $\begin{array}{c}\mathbf{2 0 0 9 / 1 0} \\
\mathbf{( \% )}\end{array}$ & $\begin{array}{c}\mathbf{2 0 1 0 / 1 1} \\
\mathbf{( \% )}\end{array}$ & $\begin{array}{c}\mathbf{2 0 1 1 / 1 2} \\
\mathbf{( \% )}\end{array}$ & $\begin{array}{c}\mathbf{2 0 1 2 / 1 3} \\
\mathbf{( \% )}\end{array}$ & $\begin{array}{c}\mathbf{2 0 1 3 / 1 4} \\
\mathbf{( \% )}\end{array}$ & $\begin{array}{c}\mathbf{2 0 1 4 / 1 5} \\
\mathbf{( \% )}\end{array}$ & $\begin{array}{c}\mathbf{2 0 1 5 / 1 6} \\
\mathbf{( \% )}\end{array}$ \\
\hline Day & $158(40)$ & $197(41)$ & $215(40)$ & $233(39)$ & $239(34)$ & $249(38)$ & $247(39)$ & $227(60)$ \\
\hline Boarding & $232(60)$ & $280(59)$ & $325(60)$ & $360(61)$ & $382(66)$ & $400(62)$ & $385(61)$ & $341(40)$ \\
\hline Total & 390 & 477 & 540 & 593 & 621 & 649 & 632 & 568 \\
\hline
\end{tabular}

Source: authors' fieldwork, 2018

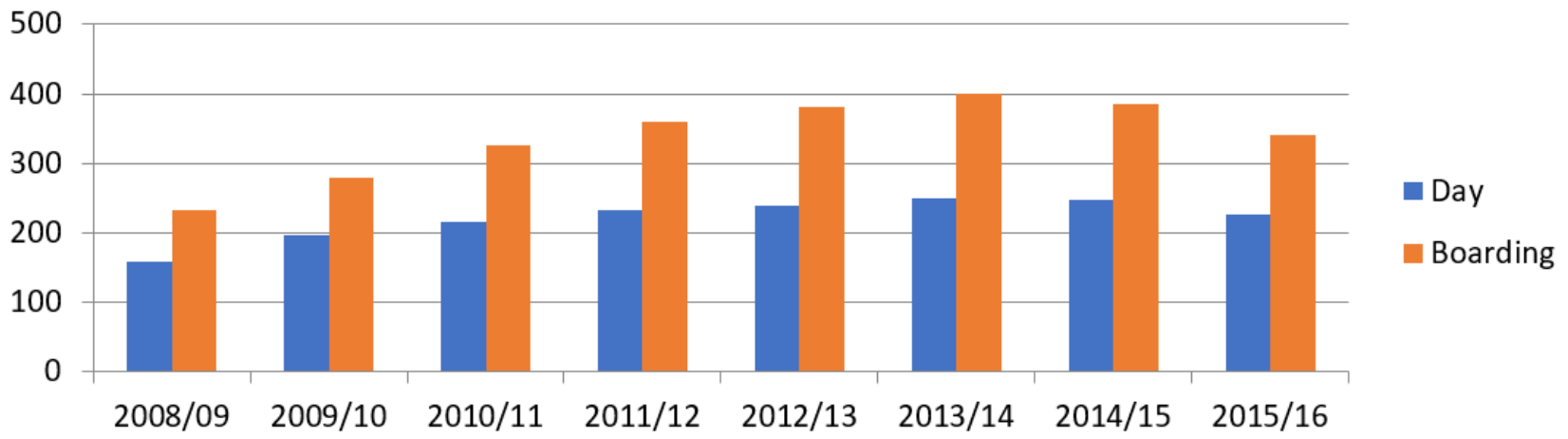

Figure 2. Enrolment trend in day and boarding schools from 2008-2016

\section{Research Question 2}

What is the enrolment trend of junior secondary schools from 2008 - 2016 in day and boarding schools? The result of the analysis is presented in Table 3.

The result in Table 3 shows that the trend of enrolment in the day and boarding junior secondary schools increased consistently from 2008/2009 with a mean of 158 for day schools and 232 for boarding schools to 2013/2014 with a mean of 249 for day schools and 400 for boarding schools. In 2014/2015, enrolment trend in both day and boarding schools started declining with a mean of 247 for day schools and 385 for boarding schools and continued declining slowly to 227 for day schools and 341 for boarding schools in 2015/2016. The analysis also indicates that junior secondary school enrolment was significant high in boarding schools than in day schools in all the years covered in the study. This is further illustrated in Figure 2.

\section{Hypothesis 1}

There is no significant difference in enrolment trend of junior secondary schools from $2008-2016$ based on school type. The result of this analysis is presented in Table 4.

In Table 4, the independent $\mathrm{t}$-test analysis indicates that $\mathrm{t}$ ratio ranging from 1.598 to 2.712 was obtained for the years under consideration. This t-ratio were all statistically significant at .05 probability level since $\mathrm{p}$ is less than .05 ( $\mathrm{p}<.05$ ); except for the first two years 2008/2009 and 2009/2010. On the basis of this result, hypothesis three was rejected except for 2008/2009 and 2009/2010. Thus, suggesting that there is a statistically significant difference between single-sex and mixed-sex schools in their enrolment for all other years, except for 2008/2009 and 2009/2010. The result further shows that enrolment in single-sex schools was significantly higher than those in mixed-sex schools. 
Pedagogical Research, 4(3), em0039

Table 4. Independent t-test comparison of school type and students' enrolment

\begin{tabular}{|c|c|c|c|c|c|c|}
\hline Year & School type & $\mathbf{N}$ & Mean & SD & $\mathbf{t}$ & p-level \\
\hline \multirow[t]{2}{*}{$2008 / 09$} & Single & 7 & 221.57 & 141.159 & 1.598 & .111 \\
\hline & Mixed & 218 & 162.90 & 94.030 & & \\
\hline \multirow[t]{2}{*}{$2009 / 10$} & Single & 7 & 267.14 & 165.589 & 1.607 & .109 \\
\hline & Mixed & 218 & 202.17 & 103.098 & & \\
\hline \multirow[t]{2}{*}{$2010 / 11$} & Single & 7 & 311.43 & 200.824 & 2.059 & .041 \\
\hline & Mixed & 218 & 221.91 & 109.839 & & \\
\hline \multirow[t]{2}{*}{$2011 / 12$} & Single & 7 & 345.57 & 211.706 & 2.173 & .031 \\
\hline & Mixed & 218 & 240.16 & 123.162 & & \\
\hline \multirow[t]{2}{*}{$2012 / 13$} & Single & 7 & 359.29 & 228.051 & 2.222 & .027 \\
\hline & Mixed & 218 & 247.45 & 127.362 & & \\
\hline \multirow[t]{2}{*}{$2013 / 14$} & Single & 7 & 380.86 & 235.088 & 2.345 & .020 \\
\hline & Mixed & 218 & 257.65 & 133.066 & & \\
\hline \multirow[t]{2}{*}{$2014 / 15$} & Single & 7 & 386.43 & 253.286 & 2.712 & .007 \\
\hline & Mixed & 218 & 254.44 & 212.370 & & \\
\hline \multirow[t]{2}{*}{$2015 / 16$} & Single & 7 & 351.29 & 229.972 & 2.532 & .012 \\
\hline & Mixed & 218 & 232.87 & 117.381 & & \\
\hline \multirow[t]{2}{*}{ Overall } & Single & 7 & 2623.57 & 1588.83 & 2.348 & .020 \\
\hline & Mixed & 218 & 1819.54 & 864.69 & & \\
\hline
\end{tabular}

Table 5. Independent t-test comparison of school composition and students' enrolment

\begin{tabular}{|c|c|c|c|c|c|c|}
\hline Year & School composition & $\mathbf{N}$ & Mean & SD & $\mathbf{t}$ & p-level \\
\hline \multirow[t]{2}{*}{$2008 / 09$} & Day & 207 & 158.80 & 87.10 & 3.28 & .002 \\
\hline & Boarding & 18 & 232.89 & 155.43 & & \\
\hline \multirow[t]{2}{*}{$2009 / 10$} & Day & 207 & 197.52 & 97.59 & 4.06 & .001 \\
\hline & Boarding & 18 & 280.94 & 157.62 & & \\
\hline \multirow[t]{2}{*}{$2010 / 11$} & Day & 207 & 215.89 & 101.89 & 4.20 & .000 \\
\hline & Boarding & 18 & 325.94 & 183.93 & & \\
\hline \multirow[t]{2}{*}{$2011 / 12$} & Day & 207 & 233.28 & 116.90 & 4.61 & .000 \\
\hline & Boarding & 18 & 360.22 & 180.46 & & \\
\hline \multirow[t]{2}{*}{$2012 / 13$} & Day & 207 & 239.45 & 121.02 & 74.09 & .000 \\
\hline & Boarding & 18 & 382.94 & 181.28 & & \\
\hline \multirow[t]{2}{*}{$2013 / 14$} & Day & 207 & 249.37 & 123.94 & 83.42 & .000 \\
\hline & Boarding & 18 & 400.72 & 207.66 & & \\
\hline \multirow[t]{2}{*}{$2014 / 15$} & Day & 207 & 247.48 & 112.34 & 110.05 & .000 \\
\hline & Boarding & 18 & 385.89 & 214.50 & & \\
\hline \multirow[t]{2}{*}{$2015 / 16$} & Day & 207 & 227.42 & 108.66 & 126.94 & .000 \\
\hline & Boarding & 18 & 341.61 & 210.58 & & \\
\hline \multirow[t]{2}{*}{ Overall } & Day & 207 & 1769.20 & 800.98 & 143.49 & .000 \\
\hline & Boarding & 18 & 2711.16 & 1433.31 & & \\
\hline
\end{tabular}

\section{Hypothesis 2}

There is no significant difference in enrolment trend of junior secondary schools from 2008 - 2016 based on school composition. The result of the analysis is presented in Table 5.

In Table 5, the independent t-test analysis indicates that t ratio ranging from 4.20 to 126.94 was obtained for the years under consideration. These t-ratios were all statistically significant at .05 probability level since $\mathrm{p}$ is less than $.05(\mathrm{p}<.05)$. On the basis of this result, hypothesis four was rejected. Thus, suggesting that there is a statistically significant difference between boarding and day schools in their enrolment. The result further shows that enrolment in boarding schools was significantly higher than those in day schools.

\section{DISCUSSION OF FINDINGS}

The enrolment trend of junior secondary schools in single-sex and mixed-sex schools was determined by the use of mean scores for each of the years covered in this study. The result of the analysis revealed that there was a steady increase in enrolment of single-sex in junior secondary schools in Akwa Ibom State from 2008/2009 up to $2014 / 2015$ and then declined in 2015/2016. It was also revealed that there was a steady low increase in enrolment of mixed-sex schools from 2008/2009 to 2013.2014, after which it started dropping from 2014/2015 and 
continued to drop in 2015/2016. This result also revealed that single-sex schools witnessed a larger increase in enrolment than mixed-sex schools in all the years observed. It was also noted that enrolment in mixed-sex schools had started declining before that of single-sex school declined.

This result could be attributed to the complex nature of mixed-sex school environment in terms of safety and harassment, especially for female students, which sometimes made parents to prefer single-sex schools for their wards. In many mixed-sex schools in the state, female students, especially those from poor homes are harassed sexually, molested by male students and sometimes, male teachers. This result supports the opinion of Park, Behrman, and Jaesung (2013) who stressed that parents tend to perceive single-sex schools as being superior to co-educated schools. In line with this, Howell, West, and Peterson (2008) also added that more than one-third of Americans support having single-sex public schooling options due to the perceived conducive learning environment associated with single-sex schools. This factor may explain why enrolment rose significantly in singlesex schools than mixed-sex schools in Akwa Ibom State.

The enrolment trend of junior secondary schools in day and boarding schools was determined by the use of mean scores for each of the years covered in this study. The result of the analysis revealed that there was a steady increase in enrolment of day and boarding junior secondary schools in Akwa Ibom State from 2008/2009 up to $2013 / 2014$ and then declined in 2014/2015, and continued falling in 2015/2016. It was also shown both schools had increased enrolment in all the years except 2014/2015 and 2015/2016 when they both started dropping at the same time. It was further noted that there was a large and significant increase in enrolment of boarding schools than day schools in all the years in question. This result suggests that secondary schools with boarding facilities had high enrolment than those without boarding facilities, in Akwa Ibom State.

The possible factor that could account for this large enrolment in boarding schools than day schools is conducive learning environment associated with boarding schools. This result is in line with the opinion of Abdullahi (2010) who maintained that there is a significant difference in reading and note taking between day and boarding students' study habits and that home environment compared very unfavourably with a school environment in which the boarders have their schedule planned by the school authorities and the schedules are supervised by the school counsellor or personnel on duty. This may explain the large increase in enrolment of boarding schools as against the residual increase in enrolment of day schools.

The result of the first hypothesis of this study revealed that there is a significant difference between the enrolment trend in single-sex and mixed-sex junior secondary schools in Akwa Ibom State in 2010/2011, 2011/2012, 2012/2013, 2013/2014, 2014/2015 and 2015/2016. The result also revealed that there was no significant difference in enrolment of single-sex and mixed-sex schools in 2008/2009 and 2009/2010. This result means that within 2008 and 2010, factors influencing enrolment in mixed-sex schools also influenced enrolment in single-sex schools in the state. The result further explains that from 2011-2016, factor influencing enrolment in single-sex schools and mixed-sex schools differ relatively, which resulted in a significant difference in the enrolment trend observed between the schools. One of the observed factors responsible for this difference is the perceived safety of students, especially the female students in single-sex schools.

This finding agrees with the results of Mburu (2013) which found that the type of school attended affected students' academic performance as the majority of the girls who qualified to join tertiary institution were from single-sex schools. This implies that students' performance, which is a key determinant of increased enrolment, can contribute to the direction of the result in that, in Akwa Ibom State, there seems to be effective teaching and learning in single-sex schools than in mixed schools, thereby attracting more students in single-sex schools. Contrary to this result, Lee, Turner, Woo, and Kim (2014) found that the significant impact of single-sex schools on male students' achievement was not driven by classroom gender composition, but largely accounted for by increases in student effort and study-time. The differences in the results of this study from that of Lee et al (2014) may have been due to the varied locations in which the studies were conducted.

The second hypothesis of this study revealed that there is a significant difference in the enrolment trend of day and boarding junior secondary schools in Akwa Ibom State from 2008-2016. The analysis indicated that p-values in all the observed in this were less than 0.05 probability level, which shows that there was a significant difference in enrolment trend of day and boarding schools in the years in question. The result further showed that $t$-values in the successive years observed were greater that critical t-values, which further strengthens the significant difference in the enrolment trend in boarding and day schools.

This result can be attributed to the performance differential in day and boarding schools in the State. Most of the boarding schools in Akwa Ibom State have conducive learning atmosphere, effective disciplinary control, and effective students' personnel service and functional school facilities, which allows for effective teaching and learning, thereby inducing increased enrolment. On the other hand, most day schools in the state do not have adequate and functional learning resources to boost effective teaching and learning, hence students exhibit all manner of negative learning behaviour, which has always led to poor performance of day schools in the State, and which led to parents' preference for boarding schools. This agrees with Ogechukwu and Chika (2018) who found 
that boarding students academically achieved better than day students and that day students are distracted at home, unlike boarding school students who are under the control of teachers for their study.

The issue of students' safety and security in the school, also account for the direction of this result. Almost all the boarding schools in Akwa Ibom State are well-fenced, with adequate security for the safety of the students. This may form the basis for increased enrolment in boarding schools as parents, especially those living in villages, prefer to enrol their children in boarding schools for safety, discipline, and effective learning. In line with this, Adetunji and Oladeji (2007) found that most of the boarding students read regularly because they have scheduled a time for reading in their curriculum, they sometimes use library and library books.

\section{CONCLUSION}

Based on the result of the data analysis, it is concluded that enrolment in junior secondary schools in Akwa Ibom State was high in single-sex schools and boarding schools, while it was low in mixed-sex schools and day schools. It is also concluded that there was an upward trend in enrolment, in all the schools from 2008-2013 and a downward trend from 2015-2016. It is further concluded that there were statistically significant differences in the enrolment trend between single-sex and mixed-sex junior secondary schools and between day and boarding junior secondary schools. Finally, it is concluded that school type and school composition significantly contribute to the variation in the enrolment trend in junior secondary schools in Akwa Ibom State during the time period.

\section{RECOMMENDATIONS}

Based on the conclusion of the study, the following recommendations were made:

1. Government through the Ministry of education should increase spending and scholarship programmes for public schools as this will go a long way to encourage parents to enrol their wards in public schools.

2. The Ministry of Education should increase awareness and publicity on co-educational schools as these will go a long way to reduce gender discrimination among parents in mixed schools.

3. Resource allocation in terms of personnel and infrastructures should be evenly distributed across the state as these will reduce rural-urban migration.

\section{REFERENCES}

Abudullahi, O. E. (2010). Comparative study of Kwara state secondary school students' study habit in the English Language: Implication for counselling. Educational Research, 1(6), 13-14. https://doi.org/10.3923/sscience.2010.514.519

Adetunji, A. and Oladeji, B. O. (2007). Comparative study of the reading habit of boarding and day secondary school students in Osogbo, Osun State, Nigeria. Pakistan Journal of Social Sciences, 4(4), 509-512.

Afu, M. O., Vivian, F. Gbobo, V. F., Ukofia, I. F. and Itakure, Z. S. (2017). Effect of gender imbalance in the enrolment of students in public secondary schools in Gwagwalada Area Council, Federal Capital Territory, Abuja, Nigeria. International Journal of Scientific Research in Education, 10(2), 201-211.

Ahmed, M. A., Oliver, N. E. and Danmole, B. T. (2017). Comparison of boarding and day secondary school students' performance in biology in Owo, Ondo State, Nigeria. Asia Pacific Journal of Education, Arts, and Sciences, 4(3), 45-50.

Anil, B., Guner, D., Delibasi, T. T. and Uysal, G. (2016). Does classroom gender composition affect school dropout? Discussion paper. Available at: ftp.iza.org/dp10238.pdf

Arop, F. O. and Owan, V. J. (2018). Institutional variables and the supervision of security in public secondary schools in Cross River State. International Journal of Innovation in Educational Management (IJIEM), 2(1), 1-11. https://doi.org/10.2139/ssrn.3286244

Arop, F. O., Ekpang, M. A. and Owan, V. J. (2018). Management of school-related variables and teachers' job effectiveness in secondary schools in Calabar South Local Government Area of Cross River State, Nigeria. International Journal of Social Sciences and Management Research, 4(8), 90-100.

Babalola, J. B. Akpa, G. O. Ayeni, A. O. and Adedeji, S. O. (2007). Access, equity and equality in Nigeria education. NAEAP Publication.

Caskey, M. M. (2006). Research on Same-gender grouping in eighth-grade science classrooms. RMLE Online, 30(4), 1-15. https://doi.org/10.1080/19404476.2006.11462037

Dang, E. I. and Bulus, E. J. (2015), The impact of finance on the academic performance of secondary school students in Akwanga Local Government of Nassarawa State, Nigeria. Journal of Social Sciences and Public Policy, 7(2), 44-54. 
Doris, A., O’Neill, D. and Sweetman, O. (2012). Gender, single-sex schooling and maths achievement. IZA Discussion Paper. Available at: ftp.iza.org/dp6917.pdf

Fabian, A. A. (2009). Does female participation in teaching affect enrolment of female students in secondary schools in Nigeria? Journal of Women's Entrepreneurship and Education, 3(4), 97-106.

Federal Republic of Nigeria (2004). National Policy on Education. Lagos: NERDC press.

Garcia-Gracia, M. and Vázquez, T. D. (2016). Mixed schools versus single-sex schools: are there differences in the academic results for boys and girls in Catalonia? International Journal of Inclusive Education, 20(2), $149-167$. https:/ / doi.org/10.1080/13603116.2015.1079269

Gneezy, U., Niederle, M. and Rustichini, A. (2003), Performance in competitive environments: Gender differences. The Quarterly Journal of Economics, 118, 1049-1074. https://doi.org/10.1162/00335530360698496

Howell, W. G. and Peterson, P. E. (2008). The 2008 Education Next-PEPG Survey of Public Opinion: Americans think Less of their schools than of their Police Departments and Post Offices. Education Next, 8(4), $12-26$.

Igberadja, S. (2014). Assessment of teachers' and principals' opinion on the causes of the low enrolment of students in technical colleges: A Delta State study. Journal of Educational Policy and Entrepreneurial Research, 1(2), $238-250$.

Jagero, N. (2012). A comparative evaluation of direct private costs in day and boarding schools after the introduction of free secondary education in the Kenyan schools. Review of Arts and Humanities 1(1), 31-41.

Kemunto, N. H. (2013). A study of factors affecting the academic performance of girls in mixed day public secondary schools in Nyamira District, Nyamira County, Kenya. An unpublished M.Ed thesis submitted to the Department of Educational Foundations, University of Nairobi.

Kessels, U. and Hannover, B. (2008). When being a girl matters less: Accessibility of gender-related self-knowledge in single-sex and coeducational classes and its impact on students' physics-related self-concept of ability. British Journal of Educational Psychology, 78(2), 273-89. https://doi.org/10.1348/000709907X215938

Kiage, J. M., Simatwa, E. M. W. and Ayodo, T. M. O. (2014). Effect of school fees and levies on enrolment of girls in Boarding Public Secondary Schools in Transmara Sub County, Kenya: An analytical study. Educational Research, 5(5), 152-165.

Kombo. D. (2005): Sociology of Education. Adprint: Nairobi Kenya

Mburu, D. N. P. (2013). Effects of the type of school attended on students' academic performance in Kericho and Kipkelion Districts, Kenya. International Journal of Humanities and Social Science, 3(4), 79-90.

Ngeno, V. C., Enose M. W. and Ayodo T. M. (2012). Cost-effectiveness analysis of educating girls in day and boarding secondary schools in Kenya: a case study of Kericho District. Available at: www.intersjournals.org/ER

Ogechukwu, O. F. and Chika, N. P. (2018). The extent of academic achievement of day and boarding secondary schools' students in Anambra State, Nigeria. International Journal of Scientific Research and Management, 6(1), 21-26. https://doi.org/10.18535/ijsrm/v6i1.el03

Onwuameze, N. C. (2013). Educational opportunity and inequality in Nigeria: assessing social back.ground, gender, and regional effects. An unpublished Ph.D. Dissertation submitted to the Department of Educational Policy and Leadership Studies, University of Iowa. Available at: http:/ / ir.uiowa.edu/etd/2598

Oredein, O. (2016). Effect of school variables on student academic performance in Calabar Municipal Area of Cross River State. Available at: https:/ / www.linkedin.com/.../effect-school-variables-student-academic-performance-ca

Papworth, B. A. (2014). Attending boarding school: a longitudinal study of its role in students' academic and non-academic outcomes. A Ph.D. dissertation submitted to the Department of Social Work Education, University of Sydney, Australia.

Park, H., Behrman, J. R. and Jaesung, C. (2013). Causal effects of single-sex schools on college entrance exams and college attendance: Random assignment in Seoul High Schools. Demography, 50(2), 447-46. https://doi.org/10.1007/s13524-012-0157-1

Schmuck, P. (2005). Same, different, equal: Rethinking single-sex schooling. American Journal of Education, 111(2), 271-282. https://doi.org/10.1086/426841

Smyth, E. (2010). Single-sex Education: What does research tell us? Revue Française de Pédagogie, 171, 47-55. https://doi.org/10.4000/rfp.1896

Sullivan, A., Joshi, H., and Leonard, D. (2010). Single-sex schooling and academic attainment at school and through the life course. American Educational Research Journal, 47, 6-36. https:/ / doi.org/10.3102/0002831209350106

Ukpong, N. N. (2017). Politics of educational policies implementation: Focus on Universal Basic Education in Akwa Ibom State. British Journal of Education, 5(13), 99-108. 